\title{
EXPERIMENTAL STUDY OF SULFUR DIOXIDE ABSORPTION INTO CARBONATE SUSPENSIONS WITH SULFITES ADDITION
}

\author{
SIMION DRĂGAN ${ }^{\mathrm{a}}$
}

\begin{abstract}
This paper presents the experimental results obtained by sulfur dioxide chemisorption into carbonate suspension with sulfites addition at different temperatures and concentration of the absorbent suspension. Presence of sulfites in the absorbent suspension has a positive influence on the global rate of the absorption process. The acceleration of $\mathrm{SO}_{2}$ chemisorption process in the absorbent suspension containing $\mathrm{MeSO}_{3}-$ $\mathrm{MeCO}_{3}$ is determined by the higher concentration of ions in the liquid phase resulted from higher solubility of $\mathrm{MeSO}_{3}$ comparative with $\mathrm{MeCO}_{3}$. The addition of $\mathrm{MeSO}_{3}$ at a concentration of $10 \%$ in the composition of the absorbent suspension determines a significant decrease of the time required for obtaining a high conversion.
\end{abstract}

Keywords: wet desulfurization, carbonate suspension, sulfites addition.

\section{INTRODUCTION}

The issue of environmental pollution is a consequence of industrial development. An industrial sector with a major environmental impact is the energy sector, which is a major source of pollution by combustion of fossil fuels [1-3]. Desulfurization of combustion gases is currently the subject of numerous experimental research and research projects that have proposed and developed numerous desulfurization processes: dry, semi-dry and wet [4-8].

Independent of the type of desulfurization process applied in a desulphurization plant, two main conditions are required:

\footnotetext{
a Babeş-Bolyai University, Faculty of Chemstry and Chemical Engineering, Department of Chemical Engineering, 11 Arany Janos str., RO-400028, Cluj-Napoca, Romania, sdragan@chem.ubbcluj.ro
} 
- the removal of sulfur dioxide from the waste gas with minimal investment and exploitation costs;

- the product must have storage capacity and can be reusable.

Researches in the field of combustion gases desulfurization are directed towards the development of technologies that produce sulfur compounds that can be fully utilized. A great prospect is the $\mathrm{SO}_{2}$ absorption process into dolomite suspension thus reducing the amount of gypsum due to the fact that part of the sulfur is recovered as $\mathrm{MgSO}_{4}$, compound with many practical uses [9].

The kinetic study of the $\mathrm{SO}_{2}$ chemisorption process into dolomitebrucite suspensions revealed that the global process takes place according to the shrinking core model without crust or according to the unreacted core model with crust formation of the reaction products [9-10]. In the temperature range $T=293-333 \mathrm{~K}$ and the suspension concentration $C=5-15 \%$ limitative steps of the global absorption process are the diffusional processes. At low concentrations of the suspension and high temperatures, the diffusion through the liquid phase to the outer surface of the granule is the determining step. At low temperatures and high concentrations of the suspension, the limitative step is the diffusion through the crust of reaction product.

\section{RESULTS AND DISCUSSIONS}

The investigations present the influence of the suspension concentration and temperature on the global rate of the chemisorption process. Preparation of the suspension containing $\mathrm{MeCO}_{3}$ and $\mathrm{MeSO}_{3}$ can be achieved if the neutralization zone of the industrial absorber is comprised of two compartments:

I. Neutralization compartment - where the following reactions occur:

$$
\begin{aligned}
& \mathrm{Mg}\left(\mathrm{HSO}_{3}\right)_{2}+\mathrm{MgCO}_{3} \rightarrow 2 \mathrm{MgSO}_{3}+\mathrm{CO}_{2}+\mathrm{H}_{2} \mathrm{O} \\
& \mathrm{Mg}\left(\mathrm{HSO}_{3}\right)_{2}+\mathrm{CaCO}_{3} \rightarrow \mathrm{MgSO}_{3}+\mathrm{CaSO}_{3}+\mathrm{CO}_{2}+\mathrm{H}_{2} \mathrm{O} \\
& \mathrm{Ca}\left(\mathrm{HSO}_{3}\right)_{2}+\mathrm{CaCO}_{3} \rightarrow 2 \mathrm{CaSO}_{3}+\mathrm{CO}_{2}+\mathrm{H}_{2} \mathrm{O} \\
& \mathrm{Ca}\left(\mathrm{HSO}_{3}\right)_{2}+\mathrm{MgCO}_{3} \rightarrow \mathrm{CaSO}_{3}+\mathrm{MgSO}_{3}+\mathrm{CO}_{2}+\mathrm{H}_{2} \mathrm{O}
\end{aligned}
$$

II. Oxidation-neutralization compartment - where the following reactions occur:

$$
\begin{aligned}
& \mathrm{Mg}\left(\mathrm{HSO}_{3}\right)_{2}+\mathrm{O}_{2} \rightarrow 2 \mathrm{MgSO}_{4}+\mathrm{H}_{2} \mathrm{SO}_{4} \\
& \mathrm{Ca}\left(\mathrm{HSO}_{3}\right)_{2}+\mathrm{O}_{2}+2 \mathrm{H}_{2} \mathrm{O} \rightarrow \mathrm{CaSO}_{4} 2 \mathrm{H}_{2} \mathrm{O}+\mathrm{H}_{2} \mathrm{SO}_{4} \\
& \mathrm{H}_{2} \mathrm{SO}_{4}+\mathrm{CaCO}_{3}+2 \mathrm{H}_{2} \mathrm{O} \rightarrow \mathrm{CaSO}_{4} 2 \mathrm{H}_{2} \mathrm{O}+\mathrm{CO}_{2}+\mathrm{H}_{2} \mathrm{O} \\
& \mathrm{H}_{2} \mathrm{SO}_{4}+\mathrm{MgCO} \mathrm{CO}_{3} \rightarrow \mathrm{MgSO} \\
& 4
\end{aligned}
$$


The $\mathrm{MeSO}_{3}-\mathrm{MeCO}_{3}$ suspension resulting from compartment $\mathrm{I}$ is recirculated in the absorption column and the slurry accumulated in compartment II is filtered and processed to recover $\mathrm{CaSO}_{4}$ and $\mathrm{MgSO}_{4}$.

The experimental study of the absorption process showed that regardless of the temperature and concentration of the suspension there is a period at the beginning of the process where the chemisorption rate is lower. The duration of this induction period extends until the $\mathrm{pH}$ of the suspension decreases from $\mathrm{pH}=6.7-7$ to $\mathrm{pH}<5.5$. In the range of $\mathrm{pH}=7-5.5$, thermodynamically stable are $\mathrm{MeSO}_{3}$ neutral sulfites, which have a low solubility. When the $\mathrm{pH}$ of the suspension decreases to $\mathrm{pH}<5,5$ the neutral sulfites $\mathrm{MeSO}_{3}$ react with $\mathrm{H}_{2} \mathrm{SO}_{3}$ to form acid sulfites whose high solubility eliminates crust formation and so, the rate of chemisorption increases. This suggests the acceleration of the $\mathrm{SO}_{2}$ chemisorption process into dolomitebrucite suspensions if the absorbent suspension also contains $\mathrm{MeSO}_{3}$ in addition to $\mathrm{MeCO}_{3}$.

The intensification of the $\mathrm{SO}_{2}$ chemisorption process in the absorbent suspension containing $\mathrm{MeSO}_{3}-\mathrm{MeCO}_{3}$ is determined by:

-the higher-concentration of ions $\mathrm{HSO}_{3}^{-}$in the liquid phase resulting from the following reactions:

$$
\begin{aligned}
& \mathrm{CaSO}_{3}+\mathrm{SO}_{2}+\mathrm{H}_{2} \mathrm{O} \rightarrow \mathrm{Ca}\left(\mathrm{HSO}_{3}\right)_{2} \\
& \mathrm{MgSO}_{3}+\mathrm{SO}_{2}+\mathrm{H}_{2} \mathrm{O} \rightarrow \mathrm{Mg}\left(\mathrm{HSO}_{3}\right)_{2}
\end{aligned}
$$

These reactions cause the increase of ion $\mathrm{HSO}_{3}^{-}$diffusion to be by the liquid phase to the outer surface of the solid granule;

-the higher solubility by an order of magnitude of the $\mathrm{CaSO}_{3}$ compared to $\mathrm{CaCO}_{3}$ and for the $\mathrm{MgSO}_{3}$ to $10^{4}$ compared to the $\mathrm{MgCO}_{3}$ [11], causing the chemisorption reactions at the outer surface of the solid granules and into volume of the solution;

- the increase of the contact surface of the reactants due to the dissolution of $\mathrm{MgSO}_{3}$, since the solid granules become more porous.

These were the theoretical bases that determined the $\mathrm{SO}_{2}$ chemisorption to be performed in $\mathrm{MeCO}_{3}-\mathrm{MeSO}_{3}$ suspensions.

Based on the experimental results, the rate constants in the range $T=$ 293-333 K and for three different concentrations of the suspension were calculated. The obtained results of the sulfur dioxide absorption into dolomitesulfite $\left(\mathrm{MeCO}_{3}-\mathrm{MeSO}_{3}\right)$ suspensions are presented in comparison with those obtained by absorption carried out only into dolomite $\left(\mathrm{MeCO}_{3}\right)$ suspensions.

The influence of the concentrations of $\mathrm{MeCO}_{3}-\mathrm{MeSO}_{3}$ suspensions on the rate of $\mathrm{SO}_{2}$ chemisorption is shown in Figures 1-8. 


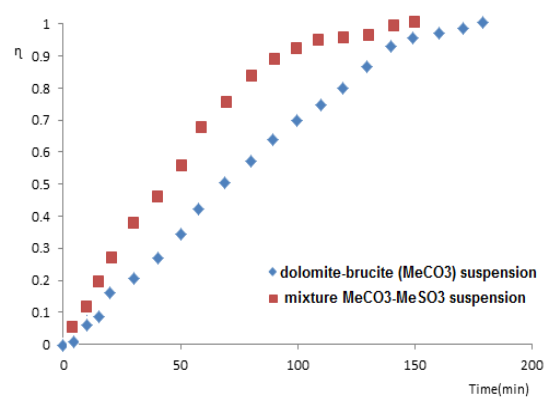

Figure 1. Absorption diagram of $\mathrm{SO}_{2}$ into dolomite-brucite $\left(\mathrm{MeCO}_{3}\right)$ suspensions, $\mathrm{C}_{\mathrm{MeCO}}=5 \%$ and in mixture of dolomite-brucitesulphite $\left(\mathrm{MeCO}_{3}-\mathrm{MeSO}_{3}\right)$ with $\mathrm{C}_{\mathrm{MeCO} 3}=5.54 \%, \mathrm{C}_{\mathrm{CaSO}}=5.62 \%$, $\mathrm{C}_{\mathrm{MgSO}_{3}}=4.33 \%$, at $\mathrm{T}=293^{\circ} \mathrm{K}$

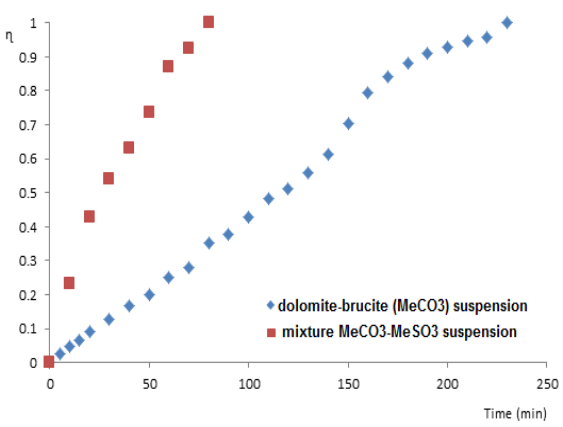

Figure 3. Absorption diagram of $\mathrm{SO}_{2}$ into dolomite-brucite $\left(\mathrm{MeCO}_{3}\right)$ suspensions $\mathrm{C}_{\mathrm{MeCO}}=15 \%$ and in mixture of dolomite-brucitesulphite $\left(\mathrm{MeCO}_{3}-\mathrm{MeSO}_{3}\right)$ with $\mathrm{C}_{\mathrm{MeCO} 3}=11.80 \%, \mathrm{C}_{\mathrm{CaSO}_{3}}=10.39 \%$, $\mathrm{C}_{\mathrm{MgSO} 3}=8.57 \%$, at $\mathrm{T}=293^{\circ} \mathrm{K}$

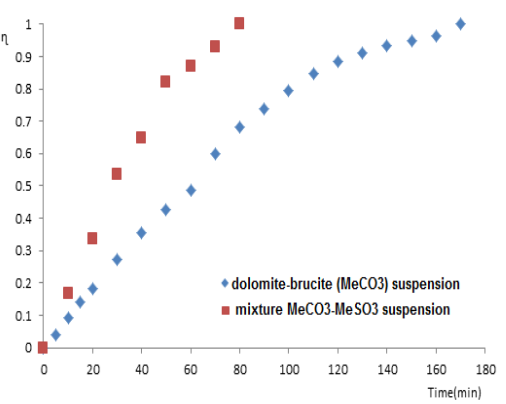

Figure 2. Absorption diagram of $\mathrm{SO}_{2}$ into dolomite-brucite $\left(\mathrm{MeCO}_{3}\right)$ suspensions $\mathrm{C}_{\mathrm{MeCO}}=10 \%$ and in mixture of dolomite-brucitesulphite $\left(\mathrm{MeCO}_{3}-\mathrm{MeSO}_{3}\right)$ with $\mathrm{C}_{\mathrm{MeCO} 3}=5.83 \%, \mathrm{C}_{\mathrm{CaSO}_{3}}=9.86 \%$, $\mathrm{C}_{\mathrm{MgSO}_{3}}=8.61 \%$, at $\mathrm{T}=293^{\circ} \mathrm{K}$

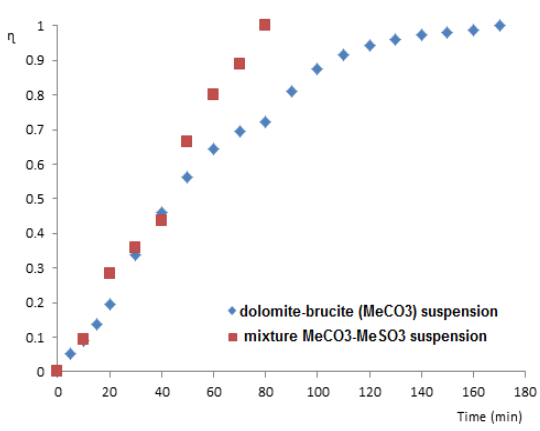

Figure 4. Absorption diagram of $\mathrm{SO}_{2}$ into dolomite-brucite $\left(\mathrm{MeCO}_{3}\right)$ suspensions $\mathrm{C}_{\mathrm{MeCO}}=5 \%$ and in mixture of dolomite-brucitesulphite $\left(\mathrm{MeCO}_{3}-\mathrm{MeSO}_{3}\right)$ with $\mathrm{C}_{\mathrm{MeCO} 3}=6.20 \%, \mathrm{C}_{\mathrm{CaSO}}=5.67 \%$, $\mathrm{C}_{\mathrm{MgSO} 3}=4.27 \%$, at $\mathrm{T}=313^{\circ} \mathrm{K}$ 


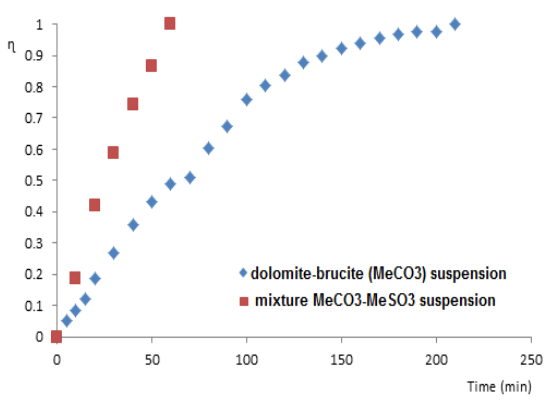

Figure 5. Absorption diagram of $\mathrm{SO}_{2}$ into dolomite-brucite $\left(\mathrm{MeCO}_{3}\right)$ suspensions $\mathrm{C}_{\mathrm{MeCO} 3}=10 \%$ and in mixture of dolomite-brucitesulphite $\left(\mathrm{MeCO}_{3}-\mathrm{MeSO}_{3}\right)$ with $\mathrm{C}_{\mathrm{MeCO}}=4.91 \%, \mathrm{C}_{\mathrm{CaSO}_{3}}=10.18 \%$, $\mathrm{C}_{\mathrm{MgSO}}=8.42 \%$, at $\mathrm{T}=313^{\circ} \mathrm{K}$

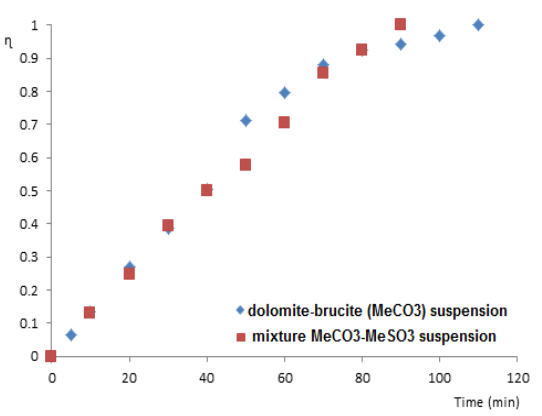

Figure 7. Absorption diagram of $\mathrm{SO}_{2}$ into dolomite-brucite $\left(\mathrm{MeCO}_{3}\right)$ suspensions $\mathrm{C}_{\mathrm{MeCO}}=5 \%$ and in mixture of dolomite-brucitesulphite $\left(\mathrm{MeCO}_{3}-\mathrm{MeSO}_{3}\right)$ with $\mathrm{C}_{\mathrm{MeCO} 3}=5.45 \%, \mathrm{C}_{\mathrm{CaSO} 3}=5.89 \%$, $\mathrm{C}_{\mathrm{MgSO} 3}=5.16 \%$, at $\mathrm{T}=333^{\circ} \mathrm{K}$

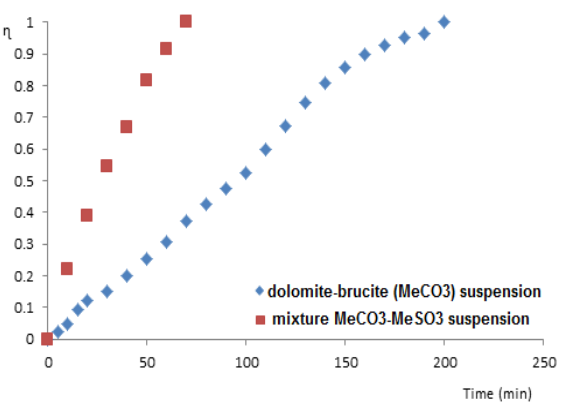

Figure 6. Absorption diagram of $\mathrm{SO}_{2}$ into dolomite-brucite $\left(\mathrm{MeCO}_{3}\right)$ suspensions $\mathrm{C}_{\mathrm{MeCO}}=15 \%$ and in mixture of dolomite-brucitesulphite $\left(\mathrm{MeCO}_{3}-\mathrm{MeSO} 3\right)$ with $\mathrm{C}_{\mathrm{MeCO} 3}=10.6 \%, \mathrm{C}_{\mathrm{CaSO} 3}=11.35 \%$, $\mathrm{C}_{\mathrm{MgSO}}=9.31 \%$, at $\mathrm{T}=313^{\circ} \mathrm{K}$

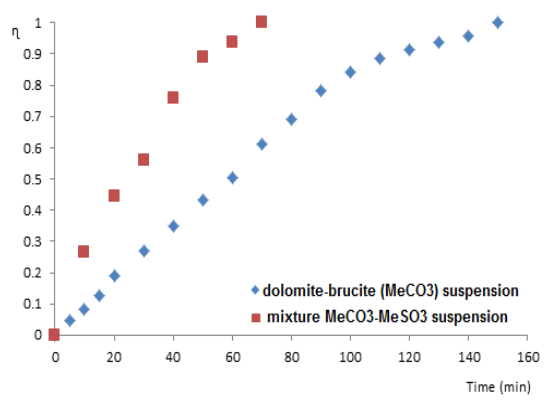

Figure 8. Absorption diagram of $\mathrm{SO}_{2}$ into dolomite-brucite $\left(\mathrm{MeCO}_{3}\right)$ suspensions $\mathrm{C}_{\mathrm{MeCO}}=10 \%$ and in mixture of dolomite-brucitesulphite $\left(\mathrm{MeCO}_{3}-\mathrm{MeSO}_{3}\right)$ with

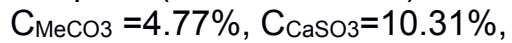
$\mathrm{C}_{\mathrm{MgSO}}=9.12 \%$, at $\mathrm{T}=333^{\circ} \mathrm{K}$

The analysis of the kinetic curves from figures 1-8, indicates that the process is very complex and is influenced by two important parameters: concentration and temperature. It can be seen that the chemisorption process takes place at a higher rate in $\left(\mathrm{MeCO}_{3}-\mathrm{MeSO}_{3}\right)$ suspensions than in $\left(\mathrm{MeCO}_{3}\right)$ suspensions. The time corresponding at conversion $\eta \geq 0.95$ to absorption in the two types of suspension is shown in Table 1. 
Table 1. Time limits required achieving conversions $\eta \geq 0.95$

\begin{tabular}{|c|c|c|c|}
\hline \multirow{2}{*}{$\begin{array}{l}\text { Conc. } \\
\text { Susp. }\end{array}$} & \multirow{2}{*}{ Temperature, $\mathrm{K}$} & \multicolumn{2}{|c|}{ Time, min } \\
\cline { 3 - 4 } & & $\mathrm{MeCO} 3$ & $\mathrm{MeCO}_{3}-\mathrm{MeSO}_{3}$ \\
\hline \multirow{3}{*}{$5 \%$} & 293 & 150 & 120 \\
\cline { 2 - 4 } & 313 & 120 & 80 \\
\cline { 2 - 4 } & 333 & 90 & 90 \\
\hline \multirow{3}{*}{$10 \%$} & 293 & 135 & 75 \\
\cline { 2 - 4 } & 313 & 180 & 58 \\
\hline \multirow{3}{*}{$15 \%$} & 333 & 128 & 60 \\
\cline { 2 - 4 } & 293 & 200 & 70 \\
\cline { 2 - 4 } & 313 & 180 & - \\
\hline
\end{tabular}

It is noted that the time required to achieve the conversions $\eta \geq 0.95$ is higher when the absorption is carried out into dolomite-brucite suspension $\left(\mathrm{MeCO}_{3}\right)$. The decrease in the time required to achieve values $\eta \geq 0.95$ in the case of the absorption of $\left(\mathrm{MeCO}_{3}-\mathrm{MeSO}_{3}\right)$ suspensions is due to the high dissolution rate of the acid sulfites formed $\mathrm{Me}\left(\mathrm{HSO}_{3}\right)_{2}$. Based on the Arrhenius law, the values of the constants rate were determined. Table 2 shows the values of the rate constants for $\mathrm{SO}_{2}$ absorption into $\mathrm{MeCO}_{3}$ suspensions compared to values obtained when the absorption is carried out in a mixture of $\mathrm{MeCO}_{3}-\mathrm{MeSO}_{3}$ suspensions.

Table 2. The rate constants of the $\mathrm{SO}_{2}$ chemisorption into $\mathrm{MeCO}_{3}$ and $\mathrm{MeCO}_{3}-\mathrm{MeSO}_{3}$ suspensions

\begin{tabular}{|c|l|l|l|l|l|}
\hline \multirow{2}{*}{$\begin{array}{c}\text { Concentration } \\
\text { of dolomite- } \\
\text { brucitic susp. }\end{array}$} & Temperature, & \multicolumn{4}{|c|}{ Rate constant } \\
\cline { 3 - 6 } & & \multicolumn{3}{|c|}{$\mathrm{MeCO}_{3}$} & \multicolumn{2}{|c|}{$\mathrm{MeCO}_{3}-\mathrm{MeSO}_{3}$} \\
\cline { 2 - 6 } & & $\mathbf{k}_{1}, \mathrm{~min}^{-1}$ & $\mathbf{k}_{2}, \mathrm{~min}^{-1}$ & $\mathbf{k}_{1}, \mathrm{~min}^{-1}$ & $\mathbf{k}_{2}, \mathrm{~min}^{-1}$ \\
\hline \multirow{5}{*}{$5 \%$} & 293 & 0,0109 & 0,0359 & 0,0153 & 0,052 \\
\cline { 2 - 6 } & 313 & 0,0146 & 0,0388 & 0,016 & 0,055 \\
\cline { 2 - 6 } & 333 & 0,0166 & 0,0442 & 0,0169 & 0,0591 \\
\hline \multirow{3}{*}{$10 \%$} & 293 & 0,0109 & 0,0244 & 0,0235 & 0,0512 \\
\cline { 2 - 6 } & 313 & 0,011 & 0,0315 & 0,0258 & 0,0562 \\
\cline { 2 - 6 } & 333 & 0,0112 & 0,0315 & 0,0283 & 0,0693 \\
\hline \multirow{3}{*}{$15 \%$} & 293 & 0,0056 & 0,0278 & 0,0257 & 0,0667 \\
\cline { 2 - 6 } & 313 & 0,0068 & 0,0311 & 0,0267 & 0,0688 \\
\hline & 333 & 0,0086 & 0,0351 & - & - \\
\hline
\end{tabular}


It can be observed that for the concentration of the suspension $5 \%$ the rate constants have higher values at the beginning of the absorption process into mixture $\mathrm{MeCO}_{3}-\mathrm{MeSO}_{3}$ suspension compared to the corresponding absorption into suspension of $\mathrm{MeCO}_{3}$.

The high concentration of $\mathrm{HSO}_{3}^{-}$in suspension determines a higher rate of the substance transformation and the transport processes. The acceleration of the absorption of $\mathrm{SO}_{2}$ into $\mathrm{MeCO}_{3}-\mathrm{MeSO}_{3}$ suspension is more pronounced at concentrations of $10 \%$ and temperature of $313 \mathrm{~K}$. In these conditions, the diffusional driving force and the dissolution rate of reaction product increase. The overall process is carried out according to the shrinking core model without crust formation. At the suspension concentrations greater than $10 \%$, the saturation concentration of solution is rapidly reached, the $\mathrm{Me}\left(\mathrm{HSO}_{3}\right)_{2}$ formed is no longer dissolved, and so the overall rate of the process decreases.

The influence of temperature on the global absorption process is represented in Figures 9-11.

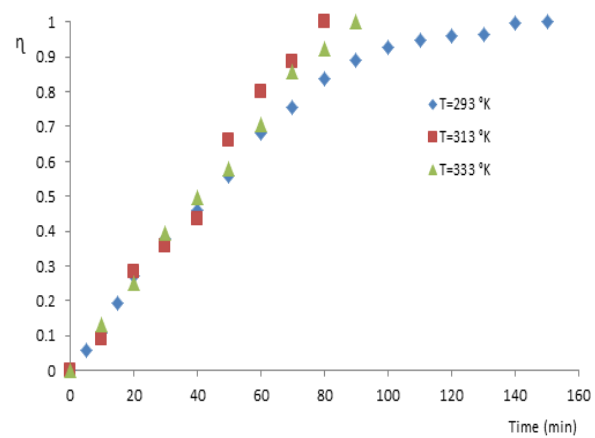

Figure 9. Influence of temperature on the $\mathrm{SO}_{2}$ absorption into mixture of dolomite-brucite $\left(\mathrm{MgSO}_{3}-\mathrm{CaSO}_{3}\right)$ suspensions at $\mathrm{C}_{\mathrm{MeCO}}=5 \%$

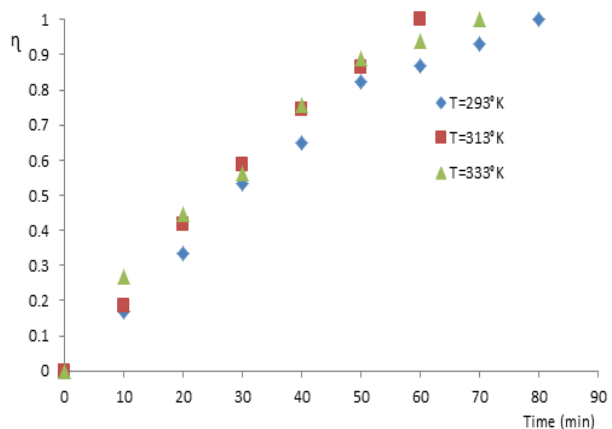

Figure 10. Influence of temperature on the $\mathrm{SO}_{2}$ absorption into mixture of dolomite-brucite $\left(\mathrm{MgSO}_{3}-\mathrm{CaSO}_{3}\right)$ suspensions at $\mathrm{C}_{\mathrm{MeCO}}=10 \%$

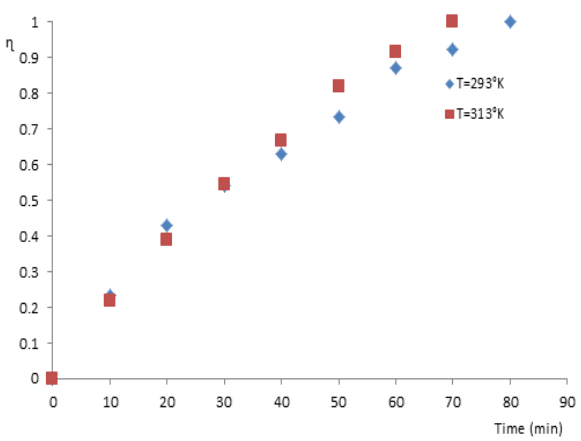

Figure 11. Influence of temperature on the $\mathrm{SO}_{2}$ absorption into mixture of dolomite-brucite $\left(\mathrm{MgSO}_{3}-\mathrm{CaSO}_{3}\right)$ suspensions at $\mathrm{C}_{\mathrm{MeCO}}=15 \%$ 
The diagrams from figures 9-11 show that for all three concentrations of the $\left(\mathrm{MeCO}_{3}-\mathrm{MeSO}_{3}\right)$ suspensions, the kinetic curves are very close at the start of the chemisorption process. Larger differences occur at low temperatures and the end of the process, when the conditions of formation of crust are met. These results confirm the transport of the $\mathrm{HSO}_{3}^{-}$through the crust with lower velocity and the global absorption process according to the unreacted core model with crust formation of reaction products.

\section{CONCLUSIONS}

The experimental results showed the positive influence of sulfites $\mathrm{MeSO}_{3}$ on the global rate of the studied process.

The rate constants of the chemisorption process were calculated for three different concentrations of the absorbent suspension. Comparative analysis of rate constants has shown values of these almost two times higher when absorption is performed in suspensions with sulfites addition.

The presence of $\mathrm{MeSO}_{3}$ at a concentration of $10 \%$ in the composition of the absorbent suspension results in a significant reduction in the time required for a conversion $\eta \geq 0.95$.

\section{EXPERIMENTAL SECTION}

The experimental research was carried out in a cylindrical batch reactor (Figure 13), with the volume of $0.4 \mathrm{I}$ at a overpressure of $98.1 \mathrm{~Pa}$. To emphasize phenomenology of processes occurring in the liquid phase and eliminate the transfer of $\mathrm{SO}_{2}$ in the gas phase, the experiment was carried out with pure $\mathrm{SO}_{2}\left(99.9 \%\right.$ of the Linde Company). Excess of $\mathrm{SO}_{2}$ was absorbed in a solution of $15 \% \mathrm{NaOH}$. Stirring of the reaction mass was performed with a magnetic stirrer at a speed of $n=200 \mathrm{rpm}$.

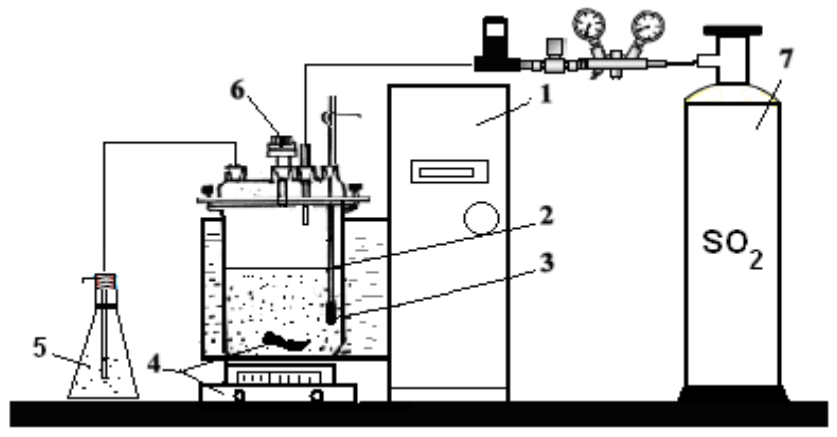

Figure. 12. The schematic of the experimental setup for $\mathrm{SO}_{2}$ absorption study:

1- ultra thermostat; 2- absorption reactor; 3- thermometer; 4 - magnetic stirrer;

5-neutralization vessel for final gas; 6 - sampling device; 7-cylinder with sulfur dioxide 
The evolution of the process was monitored by means of iodometric determination of the $\mathrm{SO}_{2}$ in the slurry. In order to compare the rate of the chemisorption of SO 2 initially were prepared suspension of dolomite with concentration of $5 \% ; 10 \% ; 15 \%$. The suspensions thus prepared were used for absorption of $\mathrm{SO}_{2}$ to constant content of the suspension. In these suspensions, whose liquid contained $\mathrm{Mg}\left(\mathrm{HSO}_{3}\right)_{2}$ and $\mathrm{Ca}\left(\mathrm{HSO}_{3}\right)_{2}$ were added amounts of dolomite: $24 \mathrm{~g}$ suspension with initial concentration of $5 \% ; 31 \mathrm{~g}$ for the suspension with the initial concentration of $10 \%$ and $45 \mathrm{~g}$ respectively for the suspension with the initial concentration of $15 \%$. The suspensions thus obtained were stirred for 12 hours at room temperature until the $\mathrm{pH}$ of the slurry increased from $\mathrm{pH}=4-4.5$ to $\mathrm{pH}=6.7-6.8$. After neutralizing $\mathrm{Me}\left(\mathrm{HSO}_{3}\right)_{2}$, the reaction was maintained at operating temperatures of $293 \mathrm{~K} ; 313 \mathrm{~K} ; 333 \mathrm{~K}$. When the temperature reaches the established values was made connection of the reactor with the source of $\mathrm{SO}_{2}$. At various time intervals were taken samples and determined $\mathrm{SO}_{2}$ by the iodometric method.

\section{REFERENCES}

1. K.J. Ladwig, G.M. Blythe, Coal Combustion Products, 2017, 67.

2. R. del Valle-Zermeno, Formosa J. and Chimenos J.M., Reviews in Chemical Engineering, 2015, 31 (4), 303.

3. I. Siminiceanu, S. Drăgan, A. Friedl, M. Harasek, Environmental Engineering and Managagement Journal. 2006, 5 (3), 433.

4. Dou, W. Pan, Q. Jin, W. Wang, and Y. Li., Energy Conversion and Management, 2009, 50 (10), 2547.

5. Mathieu Y, Tzanis L, Soulard M, Patarin J, Vierling M, Moliere M., Fuel Process Technology, 2013, 114, 81.

6. Karatepe N., Energy Source, 2000, 22, 197.

7. Hlincik T, Buryan P., Fuel, 2013a, 104, 208.

8. Hlincik T, Buryan P., Fuel Process Technology, 2013b, 111, 62.

9. S. Drăgan, Al. Ozunu, Central Eurpean Journal of Chemistry, 2012, 10 (5), 1556.

10. S. Drăgan, Adina Ghirişan, STUDIA Universitatis Babeş-Bolyai, Chemia, 2011, 56 (4), 143.

11. Masson, M.R., Lutz, H.D., Engelen, B., Solubility Data Series, Sulfites, Selenites, and Tellurites, Pergamon Press, Oxford, 1986, 441. 